УДК 347.67(477)

DOI https://doi.org/10.32837/yuv.v0i2.2150

М. Михайлів,

кандидат юридичних наук, доцент, доцент кафедри цивільного права та процесу

Львівського національного університету імені Івана Франка

\title{
ПРАВОВА ПРИРОДА СЕКРЕТНОГО (ТАЕМНОГО) ЗАПОВІТУ В МІЖНАРОДНОМУ ПРИВАТНОМУ ПРАВІ
}

Постановка проблеми. Стрімкий розвиток міжнародних приватноправових відносин вказує на потребу оновлення та удосконалення правового регулювання значної кількості сфер приватних відносин, у тому числі i спадкових. Зокрема, гармонізація спадкового законодавства 3 правом Європейського Союзу вимагає уточнення процедури складення секретних (таємних) заповітів та визначення правової природи такого виду правочину. Особа, яка склала секретний заповіт і в такий спосіб розпорядилася належним їй на праві власності майном на випадок смерті, повинна бути впевненою у тому, що іï розпорядження буде чинним, а спадкоємці зможуть отримати майно після відкриття спадщини та виконати інші умови, передбачені заповітом. Проте недосконалість норм чинного законодавства України, які передбачають складення такого виду заповіту, породжують чимало проблем у сфері нотаріальної практики та судові спори. У зв'язку із цим дослідження правової природи секретного (таємного) заповіту дасть можливість виявити суттєві недоліки у цій сфері та знайти механізми їх вирішення.

Стан дослідження. Питання, пов'язані із правовою природою секретного (таємного) заповіту, виступали предметом наукових досліджень таких українських та іноземних учених: В.В. Васильченко, Є.В. Вавіліна, Ю.Б. Гонгало, М.М. Дякович,
Ю.О. Заіки, В.В. Залєского, О.О. Кармази, Л.В. Красицької, В.І. Кисіля, Н.С. Кузнецової, О.Є. Кухарєва, Є.О. Мічуріна, В.В. Проценко, 3.В. Ромовської, Є.О. Рябоконя, Н.Б. Солтис, І.В. Спасібо-Фатєєвої, С.Я. Фурси, Г.Г. Харченко та інших.

Метою статті $€$ аналіз норм цивільного законодавства України та іноземних держав щодо регулювання питань розпорядження заповідачем майном на випадок смерті у спосіб складення секретного (таємного) заповіту, а також дослідження доктринальних підходів до природи такого заповіту. У підсумку визначити правову природу секретного (таємного) заповіту, виокремити ознаки, якими такий правочин характеризується, та запропонувати механізми удосконалення правового регулювання цих питань.

Виклад основного матеріалу. Одним із видів заповіту в державах виділяють секретний (таємний) або закритий заповіт. Правове регулювання секретних (таємних) або закритих заповітів у державах здійснюється по-різному. Так, одні держави в цивільних кодексах чи спеціальних законах закріплюють спеціальні статті (ст. 1126 ЦК Російської Федерації, ст. ст. 1365, 1367 ЦК Грузії, ст. 680 ЦК Іспанії ) та розкривають правову природу такого виду заповіту, інші закріплюють окремі положення, пов'язані із його формою (ст. 1249 ЦК України, ст. 1051 ЦК 
Республіки Казахстан, ст. 1051 ЦК Республіки Білорусь, ст. 1124 ЦК Республіки Туркменістан).

Відповідно до ст. 976 ЦК Франції коли заповідач виявить бажання скласти таємний заповіт, то папір, на якому міститься його розпорядження, або папір, який буде слугувати конвертом, у разі його наявності повинні бути закриті та опечатані. У такому вигляді заповідач передає заповіт нотаріусу і двом свідкам або доручає закрити й опечатати його в їх присутності та заявляє, що зміст цього документа $€$ його заповітом, підписаним ним і написаним ним або іншою особою, підтверджуючи в останньому випадку, що він особисто провірив зміст заповіту; у всіх випадках заповідач вказує спосіб написання заповіту (від руки чи за допомогою технічних засобів). На цьому конверті нотаріус робить надпис, який повинен містити дату і місце оформлення, опис переданого пакета і завіряє все це печаткою та ставить відмітку про виконання всіх формальних вимог. Акт з цим надписом підписує заповідач, свідки та нотаріус [1].

Можливість складення закритого заповіту передбачена ст. 680 ЦК Іспанії. Зокрема, заповідач, не проголошуючи своєї останньої волі, заявляє про те, що вона висловлена в листі, який передається особам, що посвідчують цей акт. Заповіт зберігається у заповідача або іншої особи. У нотаріуса зберігається лише протокол, який засвідчує факт складення такого заповіту [3].

Відповідно до ст. 1367 ЦК Грузії закритий заповіт складається заповідачем у присутності двох свідків, які не знайомляться зі змістом такого розпорядження, а лише засвідчують складення такого закритого заповіту та вказують, що таке розпорядження здійснювалося в їх присутності і зміст останнього їм не відомий. Проте відповідно до ст. 1365 ЦК Грузії заповідач може власноручно написати і підписати таємний заповіт і запечатати в конверт, який передати нотаріусу у присутності трьох свідків, що завіряється їніми підписами на конверті. Зберігання такого виду заповіту повинно бути забезпечено нотаріусом у спосіб його офіційного депонування нотаріусом [4, с. 678-679].

У ЦК Швейцарії теж передбачена можливість складення секретних заповітів, проте регламентацію пов'язаних з цим питань відносить не до компетенції нотаріусів, а кантонів [6, c. 284].

Відповідно до ст. 1126 ЦК Російської Федерації заповідач має право скласти заповіт, при цьому не надаючи іншим особам, у тому числі нотаріусу, можливості ознайомитися 3 його змістом (закритий заповіт). Такий заповіт має бути власноручно написаний і підписаний заповідачем. Недотримання цих правил тягне за собою недійсність заповіту. Закритий заповіт у заклеєному конверті передається заповідачем нотаріусу в присутності двох свідків, які ставлять на конверті свої підписи. Конверт, підписаний свідками, запечатується в їх присутності нотаріусом в інший конверт, на якому нотаріус робить напис, що містить відомості про заповідача, від якого нотаріусом прийнято закритий заповіт, місце і дату його прийняття, прізвище, ім'я, по батькові та місце проживання кожного свідка відповідно до документа, що посвідчує особу. Також нотаріус, приймаючи закритий заповіт, роз'яснює заповідачу наслідки порушення вимог щодо складення закритого заповіту, вкладає його в інший конверт, на якому при цьому робить відповідний напис [5].

В Україні відповідно до ст. 1249 ЦК України та ч. 3 Глави 3 Порядку вчинення нотаріальних дій нотаріусами України секретним визнається заповіт, який посвідчується нотаріусом без ознайомлення з його змістом. Особа, яка склала такий заповіт, передає його нотаріусу у заклеєному конверті, на якому має бути підпис заповідача. Своєю чергою нотаріус на конверті ставить свій посвідчувальний напис 
і скріплює печаткою та в присутності заповідача поміщає в інший конверт і опечатує [10; 11]. Також на конверті нотаріус зазначає всі дані про заповідача і ставить дату прийняття на зберігання цього заповіту. За бажанням заповідача нотаріусом може бути видане відповідне свідоцтво. Секретний заповіт приймається нотаріусом на зберігання без складання опису. Також нотаріус зобов'язаний роз'яснити заповідачу, що текст заповіту має бути викладений таким чином, щоб після відкриття спадщини не виникало неясностей чи суперечок.

Проте, виходячи із принципів нотаріальної діяльності, вважаємо, що визначення секретного заповіту, що передбачене ч. 1 ст. 1249 ЦК України, видається не зовсім коректним та правильним, оскільки нотаріус не може посвідчити заповіт без ознайомлення із його змістом. Також ця частина суперечить частині другій цієї статті, де передбачено, що нотаріус не посвідчує секретний заповіт, а ставить на конверті свій посвідчувальний напис та скріплює печаткою. Отже, нотаріус, отримавши заклеєний конверт, не може ознайомитися зі змістом заповіту, а лише на конверті може засвідчити справжність підпису заповідача. Виходячи із цього, нотаріус наділяється лише можливістю вчинити такі дві нотаріальні діï: засвідчити підпис заповідача на конверті, в якому міститься секретний заповіт, та прийняти секретний заповіт на зберігання. У зв'язку із цим ст. 1249 ЦК України потребує доопрацювання та відповідних змін.

На відміну від цивільного законодавства іноземних держав, які чітко передбачають під час передання заповідачем нотаріусу секретного заповіту присутність не менше як двох свідків, у ЦК України обов'язок посвідчення секретного заповіту при свідках не передбачений. Статтею 1253 ЦК України передбачена можливість посвідчення заповіту при свідках лише за бажанням заповідача. 3 огляду на специфіку такого заповідального розпорядження, видається за необхідне передбачити в законодавстві положення, відповідно до якого передання секретного заповіту нотаріусу відбувалося лише в присутності двох свідків, які б засвідчували сам факт передання такого заповіту та могли б підтвердити, що така особа на момент його передання усвідомлювала значення своїх дій та не піддавалася сторонньому впливу.

Отже, виходячи з аналізу законодавства держав, можемо дійти висновку, що спільним для держав, які передбачають можливість складення секретного або закритого заповіту, $€$ те, що зміст такого заповіту відомий лише заповідачу, інші особи можуть довідатися про зміст такого розпорядження лише після відкриття спадщини. Щодо форми складення такого заповіту підходи в державах відрізняються, зокрема: в одних державах обов'язково заповідач має власноручно написати такий заповіт і його підписати, в іншому випадку такий заповіт є нікчемним; окремі держави дають можливість складення такого заповіту або власноручно, або за допомогою технічних засобів; окремі держави взагалі не визначають, в якій формі має бути складено такий документ, у зв'язку із чим до форми такого заповіту будуть застосовуватися загальні вимоги щодо форми заповіту.

Різними також видаються підходи, пов'язані із місцем складення, місцем зберігання та присутністю свідків. В одних державах під час складення такого заповіту мають бути присутні свідки, в інших - під час передання на зберігання уповноваженій законодавством держави особі. В окремих державах, зокрема і в Україні, не передбачена необхідність свідків ні під час складення такого заповіту, ні під час передачі останнього на зберігання нотаріусу. Зберігання такого заповіту в державах може покладатися або на нотаріуса, або на уповноважену законодавством особу, проте в окремих державах такий заповіт

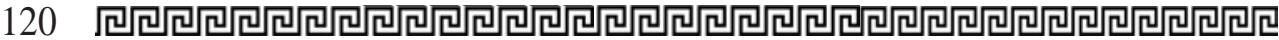


може зберігатися або у заповідача, або в інших уповноважених осіб.

3 одного боку, такий заповіт буде гарантувати таємність інформаціï щодо самого змісту такого заповіту, оскільки нотаріусу чи свідкам, які були присутні під час передання секретного (таємного) заповіту, буде відома лише інформація щодо самого факту складення заповіту, щодо його змісту вони не будуть обізнані. Проте чимало питань виникатиме щодо самого змісту такого секретного чи таємного заповіту, оскільки нотаріус не в змозі перевірити, чи відповідає він вимогам чинного законодавства і чи заповідач розпорядився тим майном, яке належить йому на праві власності, або розпорядження яким може здійснювати самостійно. Також нез'ясованим залишається і те, чи під час складення такого заповіту заповідач діяв вільно та чи усвідомлював він значення такого волевиявлення. Всі ці обставини можна буде з'ясувати лише після відкриття спадщини.

На думку Ю.О. Заіки, інститут складання секретного заповіту не має аналогів в історії вітчизняного цивільного законодавства. Недосконалість редакції статті, яка передбачає складення такого заповіту, зумовить різноманітність нотаріальної практики, запрограмованість та численні судові спори, а головне, не досягне мети, яку поставив законодавець, - запобігти можливим зловживанням з боку осіб, які посвідчують заповіти [7, с. 106].

Різний підхід до правового регулювання секретного (таємного) заповіту в державах вказує на те, що одні держави секретний (таємний) заповіт визнають як окремий вид заповіту, інші держави розглядають його крізь призму закріплених вимог щодо форми заповіту. Це своєю чергою призвело до появи доктринальних дискусій, пов'язаних із правовою природою секретного (таємного) заповіту.

Зокрема, на думку Н.Б. Солтис, секретний заповіт не доцільно виокремлювати як окремий вид заповіту, оскільки зміст такого заповіту не містить істотних особливостей, щоб виділити його в окремий вид. Його особливість полягає лише у нотаріальній процедурі посвідчення заповіту, що $€$ особливістю нотаріально-процесуальних дій, яких слід дотримуватися нотаріусу під час посвідчення заповіту [2, с. 70].

Дещо іншу позицію висловлюють С.Я. Фурса, О.Є. Кухарєв та І.П. Орлов, які вважають, що секретний заповіт $є$ різновидом заповіту. Віднесенням секретного заповіту до різновидів заповіту, на думку С.Я. Фурси, слугує такий критерій розмежування, як особливість посвідчення заповіту [8, с. 1022]. На думку О.Є. Кухарєва та І.П. Орлова, термін «форма заповіту» характеризує спосіб виявлення, а термін «вид заповіту» $€$ автономною кваліфікаційною одиницею у системі форм заповітів, що визначає зміст досліджуваного правочину [9, с. 46].

Вважаємо, що секретний заповіт є окремим видом заповідального розпорядження, якому притаманні декілька специфічних ознак: такий правочин $€$ вольовим актом особи заповідача, який самостійно визначає на засадах таємності юридичну долю прав та обов'язків на випадок смерті, тобто зміст такого заповіту відомий лише особі заповідача; зміст такого волевиявлення заповідач відображає в письмовій формі, причому самостійно визначає спосіб вираження такої форми - власноручно чи за допомогою загальноприйнятих технічних засобів; спеціальний порядок вчинення нотаріальних дій, пов'язаних із засвідченням справжності підпису заповідача на конверті, в якому міститься секретний заповіт; дотримання спеціальної процедури оголошення секретного заповіту. Щоб вирішити зазначені питання, необхідно правову природу такого виду заповіту визначити на законодавчому рівні у спосіб закріплення спеціальної статті. У зв'язку із цим та з ура- 
хуванням досвіду іноземних держав видається доцільним у ЦК Украіни передбачити спеціальну статтю «Секретний заповіт», в якій закріпити положення такого змісту: «Заповідач має право скласти заповіт у нотаріуса без можливості ознайомлення нотаріусом з його змістом (секретний заповіт). Перед складенням такого заповіту нотаріус зобов'язаний роз'яснити заповідачу наслідки порушення вимог щодо складення секретного заповіту. Секретний заповіт може бути написаний власноручно або з використанням технічних засобів із зазначенням місця та часу його складання та підписаний заповідачем. Вкладений у конверт заповіт передається нотаріусу в присутності двох свідків, які ставлять на конверті свої підписи. Конверт, підписаний свідками, запечатується в іхній присутності нотаріусом в інший конверт, на якому нотаріус робить напис, що містить відомості про заповідача, від якого нотаріусом прийнято секретний заповіт, місце і дату його прийняття, прізвище, ім'я, по батькові та місце проживання кожного свідка відповідно до документа, що посвідчує особу. Нотаріус, приймаючи секретний заповіт, вкладає його в інший конверт, на якому при цьому робить відповідний напис».

Висновки. Таким чином, керуючись принципом свободи заповіту, заповідач як суб'єкт речових відносин наділений правом на розпорядження майном на випадок смерті на власний розсуд, використовуючи при цьому різні способи та механізми реалізації таких прав. Одним зі способів реалізації заповідачем права на заповіт є складення секретного (таємного) заповіту. Правове регулювання секретних (таємних) заповітів у державах здійснюється по-різному, зокрема, відрізняються підходи до форми такого заповіту, місця його складення, місця зберігання та присутності свідків.

3 огляду на специфіку такого заповідального розпорядження, обгрунтовано необхідність передбачити в зако- нодавстві положення, відповідно до якого передання секретного заповіту нотаріусу відбувалося би лише в присутності двох свідків, які б засвідчували сам факт передання такого заповіту та могли б підтвердити, що така особа на момент його передання не піддавалася сторонньому впливу.

Звертається увага на потребу виокремити секретний заповіт як окремий вид заповіту, якому притаманні такі ознаки: такий правочин є вольовим актом особи заповідача, який самостійно визначає на засадах таємності юридичну долю прав та обов'язків на випадок смерті, тобто зміст такого заповіту відомий лише особі заповідача; зміст такого волевиявлення заповідач відображає в письмовій формі, причому самостійно визначає спосіб вираження такої форми - власноручно чи за допомогою загальноприйнятих технічних засобів; спеціальний порядок вчинення нотаріальних дій, пов'язаних із засвідченням справжності підпису заповідача на конверті, в якому міститься секретний заповіт. У підсумку викладеного запропоновано в Цивільному кодексі України закріпити спеціальну статтю «Секретний заповіт».

У статmi на підставі аналізу ццивільного законодавства України та іноземних держав досліджено правову природу секретного ( ного) заповіту. Звертається увага, що спільним для держав, які передбачають можливість складення секретного (таємного) або закриmого заповіту, є те, що зміст такого заповіту відомий лище заповідачу, інші особи можуть довідатися про зміст такого розпорядження лище після відкриття спадщини.

Встановлено, що в державах відрізняються підходи до форми такого заповіту, місия його складення, місия зберігання та присутності свідків. Акиентовано увагу на тому, що в Україні не передбачена необхідність свідків ні під час 
складення такого заповіту, ні під час передачі останнього на зберігання нотарiусу. У зв'язку із изим з урахуванням специфіки такого заповідального розпорядження обтрунтовано необхідність передбачити в законодавстві положення, відповідно до якого передання секретного заповіту нотаріусу відбувалося лише в присутності двох свідків, які б засвідчували сам факт передання такого заповіту та могли б підтвердити, щзо така особа на момент передання такого заповіту не піддавалася сторонньому впливу.

У статті звертається увага $i$ на те, щзо, виходячи із принциипів нотаріальної діяльності, визначення секретного заповіту, що передбачене ч. $1 \mathrm{~cm} .1249$ ЦК Украіни, потребує доопрацювання та відповідних змін, зокрема, це пов'язано із тим, що нотаріус не може посвідчувати секретний заповіт, а лище засвідчити справжність підпису заповідача.

Звертається увага на потребу виокремити секретний заповіт як окремий вид заповіту, якому притаманні такі ознаки: такий правочин е вольовим актом особи заповідача, який самостійно визначае на засадах таємності юридичну долю прав та обов'язків на випадок смерті, тобто зміст такого заповіту відомий лище особі заповідача; зміст такого волевиявлення заповідач відображає в письмовій формі, причому самостійно визначає спосіб вираження такої форми - власноручно чи за допомогою загальноприйнятих технічних засобів; спеціальний порядок вчинення нотаріальних дій, пов'язаних із засвідченням справжності niдnису заповідача на конверті, в якому міститься секретний заповіт. У підсумку викладеного запропоновано в Цивільному кодексі Украӥни закріпити спеціальну статтю «Секретний заповіт».
Ключові слова: заповіт, секретний заповіт, заповідач, спадкування, форма заповіту.

Mykhayliv M. The legal nature of a secret testament in private international law

Based on the analysis of the civil legislation of Ukraine and foreign states, the legal nature of the secret testament is investigated in this article. It is noted that the common feature for states that provide the possibility to make secret testament is that the content of such a testament is known only to the testator, and other persons can learn about the content of such an testament only when the inheritance becomes available.

It is established that in some states there are different approaches to the form of such a testament, the place of its preparation, the place of storage and the presence of witnesses. Emphasis is placed on the fact that in Ukraine there is no need for witnesses either when making such a will or when transferring the latter to a notary for safekeeping. In this regard, given the specifics of such a testamentary disposition, it is justified to implement to the legislation a provision according to which the transfer of a secret testament to a notary is possible only in the presence of two witnesses who could confirm that such a person has never been under the outside influence at the time of the transfer of such a testament.

The article also draws attention to the fact that based on the principles of notarial activity, the definition of a secret testament is provided in Part 1 of Art. 1249 of the Civil Code of Ukraine needs to be finalized and amended, in particular, this is due to the fact that the notary cannot certify a secret testament, but only is obliged to certify the authenticity of the testator's signature on the envelope. 


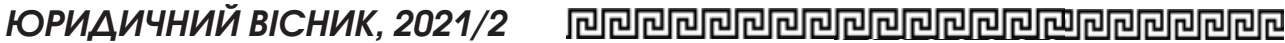

Attention is drawn to the need to single out a secret testament as a separate type of will, which has the following features: such a transaction is a voluntary act of the testator, who independently determines, on the basis of secrecy, the legal fate of rights and obligations in case of death known only to the testator; the testator reflects the content of such a will in writing, and independently determines the method of expression of such a form - personally or with the help of conventional technical means; special procedure for notarial acts related to the certification of the testator's signature on the envelope containing the secret will.

As a result of the above, it is proposed to enshrine a special article "Secret Testament" to the Civil Code of Ukraine.

Key words: testament, secret testament, testator, inheritance, form of testament.

\section{Література}

1. Civil Code of France, as of July 12013. URL: http: / / www.wipo.int / wipolex/ru/ text.jsp?file_id=450531 (дата звернення: 16.04.2021).

2. Солтис Н.Б. Житлові права у спадкових правовідносинах : монографія. Київ : Ред. журн. «Право України», 2013. 172 с.

3. Spanish Civil Code, approved by Royal Decree of July 24, 1889. Ministerio De Justicia, 2013. URL: http://derechocivil-ugr.es/ attachments / article /45/spanish-civilcode.pdf (дата звернення: 16.04.2021).
4. Гражданский кодекс Грузии. / Науч. ред. З.К. Бигвава. Перевод с грузинського И. Мериджанашвили, И. Чиковани. Санкт-Петербург : Издательство «Юридический иентр Пресс», 2002. 750 с.

5. Гражданский кодекс Росийской Федерации (часть третья) от 26.11.2001 2. № 146-Ф3 (ред. om 18.03.2019). URL: http: / / www.consultant.ru / cons / cgi/ online.cgi? $r n d=A 8 C 499660 F A 2 D 7 A 4 B 5 C F$ $B B 223 B C 1 E 2 D 8 \&$ base $=L A W \& n=320450 \&$ $d s t=4294967295 \&$ cacheid $=8 B C F D A C 90 D 6$ $780 E 7$ D 21 F6AAB20AA3349\& mode $=$ rubr\& req=doc \#046975900757217204 (дата звернення: 16.04.2021).

6. Гражданское и торговое право капиталистических государств : учебник / под. ред. Р.Л. Наришкиной. Москва: Международ. отношения, 1984. Ч. II. 304 c.

7. Заіка Ю.О. Спадкове право в Украіні: становлення $i$ розвиток : монографія. 2-е вид. Київ : КНТ, 2007. 288 с.

8. Науково-практичний коментар Цивільного кодексу України : у 2-т. / за ред. О.В. Дзери (кер. авт. кол.), Н.С. Кузнєцової, В.В. Луия. Київ : Юрінком Інтер, 2013. T. II. $1120 \mathrm{C}$.

9. Орлов І.П. Правочини у спадковому праві : монографія / І.П. Орлов, O.Є. Кухарєв. Київ : Aлерта, 2013. 270 с.

10. Порядок вчинення нотаріальних дій нотаріусами України : затв. наказом Міністерства юстиції України від 22.02.2012 p. № 296/5. URL: http:zakon5. rada.gov.ua/laws/show/z0282-12 (Jama звернення: 16.04.2021).

11. Цивільний кодекс України від 16.01.2003 p. № 435-IV. URL: https:// zakon.rada.gov.ua/laws / show / 435-15 (дата звернення: 16.04.2021). 